\title{
ResearchOnline@JCU
}

This is the Accepted Version of a paper published in the journal: Culture and Organization

Case, Peter and Gaggiotti, Hugo (2016) Italo Calvino and the organizational imagination: reading social organization through urban metaphors. Culture and Organization, 22 (2). pp. $178-198$

http://dx.doi.org/10.1080/14759551.2014.901325

(C) 2015. This manuscript version is made available under the CC-BY-NC-ND 4.0 license

http://creativecommons.org/licenses/by-nc-nd/4.0/

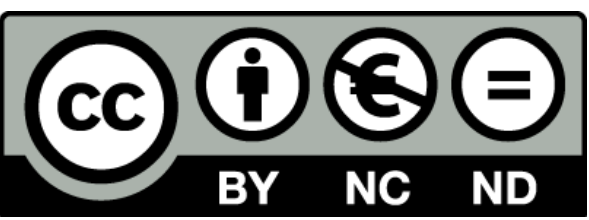




\title{
Italo Calvino and the organizational imagination: reading social organization through urban metaphors
}

Peter Case, University of the West of England and James Cook University

Hugo Gaggiotti, University of the West of England

\begin{abstract}
This article explores the way in which uses or abuses of urban metaphors can inform differing polities and ethics of human organization. From its earliest inception, the city has taken on a metaphorical significance for human communities; being, at one and the same time, a discursive textual product of culture and, reciprocally, provider of artefacts and architecture that produces culture and meaning. The city can be interpreted as a trope that operates bi-directionally in cultural terms. It is a sign that can be worked to serve the principles of both metonymy and synecdoche. In metonymical or reductive form, the city has the propensity to become weighty and deadening. The work of Michael Porter on competitive strategy is invoked to illustrate this effect. In the guise of synecdoche, on the other hand, the city offers imaginative potential. Drawing inspiration from the literary works of Italo Calvino (in particular, his novel Invisible Cities) the article attempts to reveal the fecundity of the city for interpreting technologicallymediated organizational life. Calvino's emphasis on the principle of 'lightness' provides a link to the social theoretical writing of Boltanski and Chiapello on the 'projective city'. A synthesis of these two stylistically different literatures yields a novel way of critically approaching and understanding the reticular form and emerging ethics of contemporary human organization.
\end{abstract}

Keywords: cities; urban; metaphor; imagination; organization theory; Italo Calvino 


\section{Italo Calvino and the organizational imagination: reading social organization through urban metaphors}

\section{Introduction}

I have tried to remove weight, sometimes from people, sometimes from heavenly bodies, sometimes from cities; above all I have tried to remove weight from the structure of stories and from language (Calvino 1996 [1988]: 3).

Conceptions of the city have played a central representational role in establishing the principles of organization within western civilization for at least two-and-a-half millennia. Ordering and governance of the Athenian metropolis, as found in the writings of Aristotle and Plato, for example, had a profound influence on subsequent general organizational practices of human collectives that persist to this day. The polity of Athens has, as it were, taken on an archetypal significance that casuistically extends to principles of governance in general (Jullien 2004). In our present age, cultural geographers have explored the relationship between the urban and its wider setting, arguing that landscapes and cityscapes are not only culturally produced, but that they also influence governing ideas of political, economic and religious life (Duncan 2005). Texts and discourse, in the broadest sense, are crucial to the production of human organizational relationships and to our definition and interpretation of non-human organizational relationships.

The socially constitutive and pragmatic nature of language is emphasized by Wittgenstein who employs a city metaphor thus in his Philosophical Investigations: '(And how many houses or streets does it take before a town begins to be a town?) Our language can be seen as an ancient city: a maze of little streets and squares, of old and new houses, and of houses with additions from various periods; and this surrounded by 
a multitude of new boroughs with straight regular streets and uniform houses' (Wittgenstein 1978 [1953], para 18: 8). Others, such as Roland Barthes, have suggested a direct equivalence between city and text: 'The city is a discourse, and this discourse is actually a language: the city speaks to its inhabitants, we speak our city, the city where we are, simply by inhabiting it, by traversing it, by looking at it' (Barthes 1988 [1967]: 195). Cities in the future, cities in the past, cities in our imagination; our representation of urban spaces frames and shapes organizations and informs the decisions that result from these discursive collective productions (Czarniawska 2000, 2002). In this article we seek, through a literary sensibility inspired by the writing of Italo Calvino, to explore imaginative organizational and organizing possibilities suggested by the urban; in other words, to see organizing through a metaphorical urban lens.

But what organizations do we image when, following Barthes, the urban world speaks to us? Generally, our urban images derive - in a relatively limited and limiting sense - from the mapping of space. As such they connote ideas of urban navigation, colonization, planning, control and governance. Western literature, however, has also been prolific in charting the imagined, invisible, subjective, and fantastic aspects of cities; images which - because of their 'light' and amorphous nature - have been relatively neglected by organizers whose paramount concerns have been with 'weighty' matters of utility and performativity (Lyotard 1984).

Our purpose, here, is to redress this imbalance and to attempt to tease out a new set of organizational possibilities by, in the first instance, bringing together two strands of metaphorical thinking in relation to the urban; thinking drawn from the worlds of economics and literature respectively. Two dialogues are interrogated and juxtaposed here: Michael Porter, and his dialogue with the urban world of Sassuolo in relation to 'strategic modelling', and Italo Calvino's fictional conversations with the cities of Kublai Khan's empire. With respect to Calvino, we choose to focus, in particular, on his book Invisible Cities, as this is the work in which he most directly explores the textual and 
representational possibilities of cities. We have read, compared and contrasted the original Italian edition (Calvino 1972) and a standard English translation (Calvino 1974) in order to advance our project. Calvino's last published work (in English translation) Six Memos for the Next Millennium (Calvino 1996 [1988]) and McLaughlin (1998) were also consulted in order to trace autobiographical influences on his textual attitude toward cities and literary strategies.

The article begins with an interpretative account of Invisible Cities and the selective use of images from the text to generate a critique of the weightiness and fixity of an influential economic model of organizing. The work of Michael Porter, in particular his 'diamond' model, based on the idea of how cities can contribute to the development of competitive advantage in a given region, serves to illustrate how imagination and, by implication, politics and ethics can be 'bureaucratized'. We then explain how Calvino, too, invokes the image of a diamond but, unlike Porter, uses the metaphor to introduce lightness into his cosmos of urban organization. We then proceed to a brief exegesis of Boltanski and Chiapello (2005) focussing on their sociological use of the city in understanding the complexity of justification and governance within modern and postmodern social orders. This is followed by a consideration of Calvino's interpretation of the reticular and virtual - central aspects of lightness within the projective city - which are taken up explicitly by Bauman $(2000,2003)$ in his conception of 'liquid modernity'.

The article intentionally adopts a reflexive textual strategy to weave and fabricate partial connections through its exegesis and critique of differing disciplinary takes on the urban. What serves to integrate these deliberate lines of flight is a thread of interpretative sensibility deriving from the writing and imagination of Calvino. We conclude, therefore, by reflecting back on the narrative fabric we produce and making a case for seeing organizing creatively and non-reductively through a Calvino-inspired lens of urban imagination. 


\section{Calvino's Invisible Cities}

Invisible Cities organizes itself around an imagined (anachronistic) dialogue between the merchant, Marco Polo, and Kublai Khan, emperor of a vast oriental empire. All the timeless exchanges take place in one of the emperor's palace gardens. At first Marco relates, in a seemingly inexorable flow, story upon story of cities that populate Kublai Khan's empire. But as the narrative unfolds, there occurs a subtle but definite reversal whereby the emperor himself starts to imagine various cities and asks Marco merely to confirm the verisimilitude of these accounts. In other words, the narrative focus shifts from Marco's 'empirical' tales of cities to the emperor's 'imaginary' cities, all of which occurs, reflexively, within a general fictional context. Calvino uses the text to explore in an intellectually knowing and sophisticated fashion - the possibilities and impossibilities of language and semiotics in relation to a set of deep philosophical questions. The themes that he pursues in Invisible Cities are too numerous to catalogue in detail here, but they revolve around a series of fundamental dualities which might be summarized thus: reality/fiction, material/virtual, map/terrain, signifier/signified, life/death, embodiment/disembodiment, metaphorical/literal, manifest/latent, visibility/invisibility, habitation/inhabitation, continuity/discontinuity, utopia/dystopia, lightness/weight. These polarities are not set up as structural or incommensurable dichotomies, but become - through Calvino's skilful tropical play with irony, metonymy and synecdoche - intertwined and open to infinite reversibility.

The relentless flow of city narratives are proffered in epigrammatic prose that is at once sumptuous, delicate and endlessly evocative. Calvino remarks, reflexively, on his own epigrammatic style in Six Memos thus, '... I dream of immense cosmologies, sagas, and epics all reduced to the dimensions of an epigram... I would like to edit a collection of tales consisting of one sentence only, or even a single line' (1996 [1988]: 51). Psychoanalytic themes of desire, sex, dream and the unconscious are woven together with what might be thought of as a realist anthropology of city organization and 
institution: economy, trade, merchandise, brothels, prisons, slavery and so on. These microcosmic dimensions of the city are overlaid with metaphysical preoccupations temporality, destiny, mysticism, futility - to form an intensely rich and profound exploration of the human condition.

As a way of attenuating such fecundity for the purposes of this article, we have chosen to focus exclusively on the imaginative possibilities that Calvino's cities present for modes of organizing. We contend that a reading of Calvino's city narratives can help to regenerate the way we understand and enact organization.

\section{Metaphorical uses of the city: ubiquity and reduction}

Metaphor has long been the subject of interest and debate within organization studies (Alvesson 1993; Cornelissen 2004; Oswick and Grant 1996), following its popular and influential use by Gareth Morgan in his Images of Organization (Morgan 1986). Morgan has also suggested that metaphor can be used creatively to reshape organizational theory and practice (Morgan 1989). Literature in the organization studies field suggests that metaphors could be intrinsic and inevitable to organizing (Cornelissen 2004, Cornelissen et. al. 2005; Grant and Oswick 1996; Putnam et al. 1996; Putnam and Boys 2006) and also for the practice of organizational theorizing (Weick 1989). Corneilssen (2006), following Weick (1989), has suggested that organizational theory construction has to follow a process of 'disciplined imagination', shifting from a rule base generation to a topology of metaphors that help to create variations in the way of imagining.

Our point is that while metaphor operates ubiquitously within both everyday and specialist discourse (Lakoff and Johnson 1980) the relative value of its usage varies considerably. Within organization studies, for example, we find many metaphors employed to aid understanding and promote enactment of organizational relationships 
at different levels of analysis: geo-political, macro-economic, institutional, departmental and individual. Some of these even use the image of the city explicitly for performative effect. We argue, however, that such metaphorical explorations seem often to necessitate what Burke (1968: 225-9) refers to as the 'bureaucratization of the imaginative'. In other words, viewed from our reading of Calvino, metaphors found in organization theory frequently invoke and infuse 'weight' into their rendering of organizational relationships and, as a consequence, rapidly become moribund. Think of the deadening propensity of Maslow's pyramidal 'hierarchy of motivational needs' (Maslow 1954), for example, or Handy's fourfold 'cultural typology' of organization (Handy 1977) in the context of their being endlessly reproduced in organizational behaviour lectures to successive years of hapless first-year undergraduates.

While instances of deadening metaphor can be found proliferating throughout the organization studies literature, it is the performativity (Lyotard 1984) of certain economically informed models of organization that impose the most pronounced limitations and stultifying effects on the organizational imagination. It is not that economic thinking, in general, should play no part in developing the field of organization studies (although, clearly, there has been and still is protracted debate concerning what form that economic thinking might take (McCloskey 1995). Rather, it is the metonymical reduction that is so often entailed in economic modelling, coupled with its unquestionable dominance of mainstream business and administrative discourse that, we suggest, effectively squeezes out and marginalizes organizational imagination.

We find support and justification for exploring the relationship between literature and economics in the writings of McCloskey (1990, 1995, 1998). Following McCloskey, we note that concepts like 'cities', 'markets', 'companies', and so forth, are not intrinsically or essentially economic, literary, social theoretical or philosophical. Rather they are subjects, concepts, words or metaphors employed in discourses and analyses to imagine and, by implication, instantiate various forms of social relations; be this through 
economics, literature, social theory, philosophy or any other genre of expression. McCloskey (1990), for example, does not distinguish between genres when discussing authorial intentions:

In a well-done novel or a well-done scientific paper we agree to submit to the authorial intentions, so far as we can make them out ... [and] the argument can be pushed further. An economist expounding a result creates both an 'authorial audience' (an imagined group of readers who know that this is fiction) and a 'narrative audience' (an imagined group who do not). (1990: 12)

A similar argument can also be made about relative precision and self-criticism. By engaging in a particular representational act using natural scientific or mathematical methods, McCloskey (1998: 6) contends that the result could be 'less precise and less self-critical than the better dress designer'. In other words, science and mathematics cannot necessarily make privileged claims regarding precision or critique vis-a-vis artistic endeavours. It is a matter of invoking inter-subjectively different criteria in differing representational contexts.

For McCloskey, moreover, modes of explanation are more blended in economics than in other natural and social sciences. The discipline of economics can be seen as simultaneously a science and as an expression of literacy culture while, in equal measure, literary culture could be viewed through the lens of economic science. What draws together economic, literary, social theoretical or philosophical readings of social organization for McCloskey (1998) is the art of rhetoric. In her critique of Posner's Economics Analysis of Law, for instance, terms like 'allocate', 'maximize', 'value', and 'scarcity', 'are technical words in economics, with precise definitions', which are used by Posner 'in wider senses, to evoke scientific power, to claim precision without necessarily using it' (McCloskey 1998: 3). 
We agree with McCloskey when she insists that economists are 'like other human beings in that they both use metaphors and tell stories' (1990: 7). In the context of this article, our literary interpretation of the 'city' metaphor enables us to critically interrogate an example of economic rhetoric and storytelling, namely, that of Michael Porter's 'diamond' model of national economic advantage (Porter 1990a, 1990b). By comparing Porter's metaphorical use of the city with that of Calvino (and, later, Boltanski and Chiapello) we intend to demonstrate the imaginative and theoretical value of privileging synecdoche over metonymy ${ }^{1}$ in accounts of organizational life. Whereas Porter proffers, as it were, a metonymically heavy economic account of the city, Calvino explores the evocative power and lightness of synecdoche; a use of the urban which moves beyond sheerly economic relations. This move on our part is, itself, rhetorical and one intended to upset the balance of privilege frequently afforded to mainstream economic accounts of organizational relations. To this extent, our purpose echoes Lorraine Code's (1987) injunction regarding the pursuit of 'epistemic responsibility' needed to rebalance knowledge-claims between scientific and literary discourses.

To illustrate our argument, then, we have chosen to examine the symbolism of one example in depth - a representative anecdote - rather than consider multiple cases, as this would not be feasible within the confines of a journal article. Justification for our choice of Porter's diamond is based on the fact that he is one of the most prominent economists of recent times and the kind of modelling represented in the diamond epitomizes the set of problems we are concerned to expose. Porter's discourse is used as a foil to foreground ways in which Calvino's city images could be embraced to promote 'lighter' and subtler possibilities for critically interpreting and representing processes of organizing and organization. 


\section{Diamonds are forever?}

Michael Porter's 'diamond' representations of national competitive advantage (Porter 1990a, 1990b) provide a fascinating example of how metaphor - in the context of this article one relating to the city, region and nation - can emerge and find currency within business school, organizational and government discourse. The economic interaction of nation states, in Michael Porter's imagination, can usefully be reduced to an analysis of causal conditions that originate in urban contexts. He posits the regional city as comprising a productive 'cluster', 'organized' efficiently and gaining competitiveness from an order that can be represented in the shape of a 'diamond'. Porter is widely recognized in both academic and practitioner circles as one of the most influential thinkers in the field of contemporary strategy. His profile was markedly enhanced internationally with the publication of Competitive Strategy (1980), which rapidly became a standard text on the subject of corporate strategy, as exemplified by the fact that it is, at the time of writing, in its 63rd printing in English and has been translated into nineteen languages. Interesting from our point of view is that the 'Five Forces' model of corporate competitive advantage (Porter 1979) acts as a kind of symbolic precursor to the 'diamond' metaphor that Porter (1990a, 1990b) introduces in subsequent publications.

\section{INSERT FIGUE 1 ABOUT HERE}

The Five Forces model, which can be positioned as emerging from a line of neo-classical economic thinking, presents a series of four factors impinging on a fifth, and central, element of industry rivalry (see Fig. 1). Although not yet assuming the form of a rhomboid/diamond per se, by rotating the figure on any axis by 45 degrees, a diamond form emerges. Porter's work on competition at the national level appears to have performed this rotation and, in an outward move, extended the factors from a 'corporate' to a 'regional' and 'national' context (Porter 1990a, 1990b). 
Porter popularized the concept of 'clusters' in his book The Competitive Advantage of Nations (1990a). This work argues that the economic activities of cities and regions are key to understanding the comparative competitive advantage of nation states and develops principles which, in a reverse move, can then be applied to the 'lower level' organizational unit of analysis (Porter 1990b). Porter uses the 'diamond' as a metaphorical image to explain the concept of economic 'cluster'. The four elements of the model - (a) firm structure, strategy and rivalry; (b) factor conditions, (c) demand conditions; and, (d) related and supporting industries - constitute the four corners of the diamond image (see Fig. 2).

Porter's diamond is usually represented as a rhomboid with a cross in the middle. Lines link vertices and have arrows in both directions, suggesting mutual causal influences and relationships. The diamond is two-dimensional and not represented in perspective. Despite the fact that a diamond is a three-dimensional object, the literature refers to it as a 'diamond' and not as a rhomboid, square or other two-dimensional geometrical figure.

Porter uses the diamond to illustrate an analytical argument that seeks to explain how cities and regions facilitate the geographical clustering of economic forces that, in turn, confer competitive advantage to a given city or region over others. Indeed, in its strongest form, Porter's claim is that it is not possible for competitive advantage to arise in the absence of the conditions represented by the diamond acting as a nexus within a given city or region.

\section{INSERT FIGURE 2 ABOUT HERE}

Porter's official Harvard Business School website 'Biography' refers to the book in which the diamond appears (Porter 1990a) as offering, 'a new theory of how nations and 
regions compete and their sources of economic prosperity' (Porter on-line). Claims are also made regarding the universal relevance of the theory and its wide ranging impact on policy and practice globally. Quoting directly from the site, 'Motivated by his appointment by President Ronald Reagan to the President's Commission on Industrial Competitiveness, [The Competitive Advantage of Nations] has guided economic policy in countless nations and regions. Subsequent articles have expanded on the concept of clusters (geographic concentrations of related industries that occur in particular fields) and other aspects of the theory' (Porter on-line). In a letter replying to critics, Porter (2007) reinforced the idea of a universal application of the diamond-cluster metaphor to any kind of organization referring to it as, 'neutral, rather than about picking winners, intervention, protection and subsidies. Clusters are good in any field because they boost productivity and innovation, and cluster policy seeks to reduce constraints and encourage externalities to raise the productivity of competition' (2007:18).

Porter's diamond invokes images of an alchemical process that resonate with contemporary economic aspirations regarding wealth creation. Case and Phillipson (2004) make reference to the astrological and alchemical bases of four-by-four matrices typically used to represent organizational processes, relationships and typologies within the social sciences ${ }^{2}$. Drawing on Jung's studies of alchemy, they suggest that there may be an archetypal appeal to such structures of thought. The archetype, of course, features centrally in the alchemical search for the philosopher's stone (lapis philosophorum) which will transform base metal into gold. Central to this search, as Jung (1953-83, vol.16: 203-7) illustrated, are mediaeval representations of the four astrological elements - earth, air, fire and water - and their relationship to the philosopher's stone or waters of life (aqua permanens) depicted typically as the fifth, transcendental, element. Within both Porter's 'Five Factor' and 'diamond' models, we find parallel manifestations of the alchemical archetype, that is, admixtures of four elements giving rise to a desired fifth element of 'competitive advantage' (corporate or national). If a city/region or, indeed, a firm/organization is capable of bringing the four 
forces together in an economic alembic, there opens out the possibility of 'magical' transformation. Base metals can, really, be turned into gold, or, rather - to pursue Porter's own imagery - the metaphorical diamond can transmogrify into the literal diamond of economic wealth through competitive advantage. The base 'concrete' of the city and regional infrastructure transforms into equally concrete value. Here we witness the diamond metaphor performing a kind of magic-through-connotation.

The critique of Porter's diamond that we offer might, in the language of alchemy, be viewed as revealing a certain predilection toward the saturnian on our part; that is, a tendency toward pessimism and melancholy. Such an attitude is consistent with a critical stance that derives, as in this case, from a reading of Calvino. From accounts in Six Memos, it is clear that Calvino has an appreciation of alchemy and astrology based, in part, on his reading of Jung and general assimilation of classical mythology, which act as important sources of literary inspiration. For example, he draws explicitly on imagery from the Greek and Roman pantheons in his self-revelatory portrayal of narrative disposition. Calvino claims to write 'under the sign' of Hermes-Mercury, Olympian god of communication and mediation, 'who, under the name of Thoth was the inventor of writing and who - according to C.G. Jung in his studies of alchemical symbolism - in the guise of "spirit Mercury" also represents the principium individuationis (1996 [1988]: 51$2)^{3}$. The image of Mercury, flighty winged messenger, also alludes to the qualities of lightness, agility, flexibility, adaptability and freedom so beloved of Calvino. This attitude contrasts with that of Saturn, whose 'melancholy, contemplative, and solitary' (1996 [1988]: p.52) nature he also felt close affinity with and which often symbolizes a level of discontentment with the world. As Calvino remarks, 'My cult of Mercury is perhaps merely an aspiration, what I would like to be. I am a Saturn who dreams of being a Mercury, and everything I write reflects these two impulses' (1996 [1988]: p.52).

We are not attributing any conscious intention to Michael Porter in his imaginative representation of the city as an inspiration for a cluster 'theory' of economic prosperity. 
Indeed, we do not know why he called it a 'diamond' and not a rhomboid, for example. We are suggesting, however, that it is more than coincidental that the diamond is an attractive, noble mineral, signifying value, health, and hence, perhaps, may be inspirational for business-minded publics. Simple images of richness in a cultural epoch marked by raw capitalist greed and excess seem to have favoured equally simple and limited metaphors. Certainly, these resonances might have appealed to Thatcherites and Reaganites of the eighties and early nineties at a moment when individual capital accumulation and advancement were so valorised. Under such conditions, Michael Porter seeks to explore the utility and performativity of the diamond in modelling real economic relations. Consider the following passage, for example, in which an Italian city is invoked in a demonstration of the diamond metaphor's practical application:

The development of the Italian ceramic tile industry's competitive advantage illustrates how the diamond of national advantage works. [The Italian city of] Sassuolo's sustainable competitive advantage in ceramic tiles grew not from any static or historical advantage but from dynamism and change (Porter 1990b, p.81, emphases added).

By interesting coincidence, Calvino also invokes the metaphor of the diamond in one of the dialogues between Marco Polo and Kublai Khan, but, as if speaking directly to the economic attenuation of the imagination implicit in the Porter extract, this trope contains a cautionary tale regarding the search for metonymical structure and the reductive uses of 'premature calculation' to cope with complexity. Here is an extract from the exchange in question:

'And yet I know,' [Kublai Khan] would say, 'that my empire is made of the stuff of crystals, its molecules arranged in a perfect pattern. Amid the surge of the elements, a splendid hard diamond takes shape, an immense, faceted, transparent mountain. Why do your travel impressions stop at disappointing 
appearances, never catching this implacable process? Why do you linger over inessential melancholies? Why do you hide from the emperor the grandeur of his destiny?'

And Marco Polo answered: 'While, at a sign from you, sire, the unique and final city raises its stainless walls, I am collecting the ashes of the other possible cities that vanish to make room for it, cities that can never be rebuilt or remembered. When you know at last the residue of unhappiness for which no precious stone can compensate, you will be able to calculate the exact number of carats toward which that final diamond must strive. Otherwise, your calculations will be mistaken from the very start (Calvino 1974, p.60, added emphases).

Marco Polo's words are reminiscent of the warnings of another Porter - not Michael but Theodore - whose work in the fields of sociology and history of statistics challenges western civilization's seemingly unquestioning allegiance to, and fascination with, regimes of calculation (Porter 1995). We are with Calvino and Marco Polo in recovering the 'ashes of other possible cities' which have been excoriated or occluded by the imperative push for adequate economic representations - putative diamonds - in the modelling of social relations. But Calvino did not invoke the diamond only to show the limits and dangers of dense metaphorical representations. As McLaughlin (1998: 101-2) suggests, Invisible Cities owes much to Calvino's fascination for the disciplines of mathematics and chemistry. The structure of the book follows an architectural crystal pattern (filigrana) of eleven categories - Memory, Desire, Signs and so forth, which can be designated a-k - of five cities each (1-5) distributed in the nine chapters of the book. Behind the lines and the dialectical games Marco plays in the dialogues with the Khan, a formal alphanumerical diamond gives shape to the text (see Fig. 4). Following the structural analysis of Milanini (1990: 130-1), McLaughlin (1998: 102) discerns two diamond patterns within Invisible Cities: one involves a progressive sequence (abcdefghijk) of the city categories, whilst the other is a regressive numerical series 
(54321), with each number representing the appearance of a particular category of city in the narrative. As in the fictional works of Jorge Luis Borges - an author who inspired and influenced Calvino - reality is reflected and copied but also constructed with more originality than reality itself (see, for example, Borges 1941 [1939]). The formal symmetry of the diamond is used to organize the cities, the categories and the chapters in a supposed order that, at the same time, construct them as an urban cosmos.

\section{INSERT FIGURE 3 ABOUT HERE}

Reading Calvino offers the possibility of re-contextualizing the role of the economic within 'cities' with respect to many other relatively neglected (at least in organization

studies terms) modes of explanation and enactment. The principles of lightness and critique combine with an understanding of the limits of dense metaphors to build representations that demonstrate how realities come together within a secret filigrana and which, within the overall narrative effectively 'draws' a cosmological order for the reader. In contrast to rigid or fixed interpretations, such as those of Porter, Calvino's multidimensional diamond thus restores the centrality of the organizational imagination of the reader.

\section{The projective city}

Concerns about the modelling of social relations pursued within economic discourse of the kind represented by Michael Porter's diamond leads us to search elsewhere for alternative images of the city which are more representative than narrowly reductive. Accordingly, we turn to a stylistically different literature that employs the city as an imaginative metaphor in its pursuit of a critique of capitalist political economy and the contemporary ethics of performativity. In this section of the article, we consider parallels between the richly textured semiotics of Calvino's Invisible Cities and the more 
prosaic, yet original, sociological narrative analysis of capitalism's evolution offered by Boltanski and Chiapello (2005).

Ours is, by necessity, a selective reading of Boltanski and Chiapello ${ }^{4}$, focussing specifically on their metaphorical use of the concept cités - a term which they borrow in this context and elaborate upon from Boltanski and Thévenot $(1991,2006)$. Cités may be translated from French to English as meaning, literally, 'cities', but in a philosophical and social theoretical sense it can also carry the connotation of 'world' or 'imaginary'. This double entendre forms a fruitful point of connection with Calvino's conception of the city, since it captures the sense in which the urban connotes not only architectural bricks and mortar but also extends to embrace the notion of worldviews or life-worlds. It is the imaginative fecundity of cités, or cities, which prompts us to draw parallels between the work of Boltanski and Chiapello and Calvino. Another major point of connection between the two works is the principle of 'lightness' which, whilst providing a generally positive value for Calvino (1996) with respect to the art of writing, is rendered more ambivalent and ethically challenging for networked organization and society in the hands of Boltanski and Chiapello (2005) $)^{5}$. In order to forge the relationships we see between Bolatanski and Chiapello and Calvino, we offer a brief and exegesis of The New Spirit of Capitalism which focuses on the role of the city metaphor.

The New Spirit of Capitalism consists in a neo-Weberian analysis of the evolution of capitalism as a mode of social organization, paying particular attention to the shifting phases of ideology, by which Boltanski and Chiapello mean sets of motivational and ethical justifications, that accompany capitalism's historical development. They suggest that it is possible to identify three more or less distinct periods of capitalism's evolution in which different ideologies, or 'spirits', respectively find dominance ${ }^{6}$.

The first spirit, which we associate with the industrial revolution of the eighteenth and nineteenth centuries, focuses on the bourgeois entrepreneur and invokes an ideology 
which justifies bourgeois values. The ideology celebrates the entrepreneur as captain of industry, the conquering hero [sic], and stresses the role of speculation, risk and innovation. Workers are emancipated from local agricultural communities and there are demographic and geographical shifts toward industrializing cities. A second phase of capitalism's ideological development occurs broadly between the 1930s and the 1960s. In this period, the bourgeois individualism of the first spirit is replaced by the centrality of the bureaucratized industrial firm, itself marked by, amongst many other features, a separation of ownership and control. Faith in engineering, rationality, long-term planning and the 'very gigantism' (2005: 18) of organizations in an era of mass production and mass consumption offered new forms of security. Economic science provided an apparent means of supplying value-neutral justifications for capitalism based primarily on the equivalence of personal capitalist advancement and collective utility - in the form of consequentialist and utilitarian ethics. The third and current spirit of capitalism (at least as experienced in western developed economies), whose origins Boltanski and Chiapello trace to the 1960s, is characterized by a shift away from mass bureaucratization toward more reticular forms of organization, production, and consumption associated with flexible capital accumulation.

Before we expand a little further on this third spirit, however, it is necessary to explain Boltanski and Chiapello's use of the 'city', conceived as an ideal-type, in explaining the phases of capitalism's development. The 'city' is understood to be a site or locus of justification and accountability with respect to social justice and as such can be employed metaphorically to explore the polity and ideology of a given society. It is important to note that the meaning of cités in this context is not limited to its literal urban associations. In Boltanski and Chiapello's words:

Cities are metaphysical political entities which, by the same token as cultures or languages, have a historical existence, and can therefore be situated in time and space... At a given historical moment, a form of existence is identified and 
generalized in such a way as to serve as a support for a definition of the common good and a criterion for judgements about the value of beings, according to the contribution they make to the good of all thus conceived (2005: 520).

Drawing explicitly and extensively on earlier work by Boltanski and Thévenot (1991, 2006), Boltanski and Chiapello refer to 'six logics of justification' that, in various admixtures, inform the first and second spirits of capitalism. On Justification proposes six conceptions of justice which, 'contain the principles for creating different kinds of hierarchies', and also, 'represent the normative core of an entire conception of society, or even of an entire lifeworld' (Honneth 2010: 382). Boltanski and Thévenot's choice of cités as a metaphor for justificatory order is not accidental since, as Honneth notes, it is intended to evoke 'conceptions of an entire way of life, of a comprehensive set of norms and practices' (ibid: 382). Whereas for Boltanski and Thévenot $(1991,2006)$ cités is one of a range of metaphors, alongside such notions as 'worlds', 'communities', used to address justificatory order, Boltanski and Chiapello (2005) are more direct and unequivocal in their invocation of the 'city' as an ideal type. They explicitly invoke six forms, each of which is associated with a justificatory status hierarchy and moral order. These are as follows:

1. The inspirational city - 'high status pertains to the saint who achieves a state of grace, or the artist who receives inspiration. It reveals itself in the clean body prepared by ascesis [spiritual discipline], whose inspired manifestations (holiness, creativity, artistic sense, authenticity, etc.) constitute the privileged form of expression' (ibid., p.23).

2. The domestic city - 'high status depends upon people's seniority in a chain of personal dependencies. In a system of subordination established on a domestic model, the political bond between beings is conceived as a generalization of the generational link, combining tradition and proximity. The "great man" [sic] is the 
elder, the ancestor, the father, to whom respect and fidelity are due and who vouchsafes protection and support' (ibid., p.23).

3. The reputational city - 'high status depends exclusively on the opinion of others - that is to say, on the number of people who confer their trust and esteem' (ibid., p.23).

4. The civic city - "The "great man" is the civic city is the representative of a collective whose general will he expresses' (ibid., p.23).

5. The commercial city - 'the "great man" is he who enriches himself by supplying highly desirable commodities in a competitive market, by successfully passing the market test' (ibid., pp.23-24).

6. The industrial city - 'high status is based upon efficiency, and defines a scale of professional abilities' (ibid., p.24).

The second spirit of capitalism rests upon justifications that represent a compromise between the industrial and civic cities (and secondarily the domestic city) whereas the first spirit, by contrast, invokes a compromise between the domestic and commercial cities. In On Justification, Boltanski and Thévenot (2006) derive each of the city ideal types from what they take to be foundational texts of a given historical epoch. So, for example, the inspirational city is developed out of St. Augustine's study of grace in City of God, characteristics of the civic city come from Rousseau's Social Contract, the commercial city owes much to Adam Smith's The Wealth of Nations, and so forth.

In order to understand the third spirit of capitalism, however, Boltanski and Chiapello argue that a new set of justifications is required that cannot be isolated to any singular corpus as in the case of the six cities above. The network ideology of the projective city, as they label the new ideal type, instead must be distilled from a wide range of managerial discourse. ${ }^{7}$ Accordingly, they set about subjecting two corpuses of popular management texts drawn from the 1960s and 1990s to a process of content analysis using the Prospero@ computer programme and coding at a detailed semantic and 
syntactical level (Boltanski and Chiapello 2005, pp.546-53). From this analysis they develop a 'grammar' of justifications that, they contend, are characteristic of the projective city and distinguish the third ('new') spirit of capitalism functionally and ethically from the first two. Space prohibits close interrogation of their sample, methods and findings ${ }^{8}$, but their depiction of the projective city is germane to the lines of argument we are pursuing in this paper. Other authors have expressed ethical concern about the increasing 'projectification' of society. ${ }^{9}$ Boltanski and Chiapello lend significant force to this critique by exploring the grammar and architecture of the projective city whose origins, they demonstrate, can be traced largely to AngloAmerican management writing and practice.

Boltanski and Chiapello contend that whereas the first spirit of capitalism emphasised an 'ethic of saving' and the second an 'ethic of work and competence' (2005: 151), the new spirit (epitomized by the projective city) heralds a change of societal members' relation to both money and work (2005:151). In order to illustrate the particular shift in relations referred to, we shall quote Boltanski and Chiapello at some length:

Thus is isolated in the relation of property to objects the component that corresponds to the mode of existence in the world of the projective city: availability, without the constraints of property or those of power. Human beings adjusted to a connexionist world will thus prefer, for example, to rent their main residence, since they often have to change it, or the cars they drive. This, in particular, is what distinguishes the streamlined human being of the projective city from the traditional figure of the bourgeois, who is always associated with heaviness, with weight (caricatures invariably represent him [sic] as fat). Renting is the form suitable to the project, to arrangements for a temporary operation... To full, outright ownership, it is therefore reasonable to prefer ready, temporary access to resources that are borrowed, employed or expended in the framework 
of the project, while maintaining sufficient flexibility to refund them when required (2005:153, original emphases).

\section{Calvino's principle of 'lightness' and contemporary capitalism}

The networked organization of contemporary capitalist society thus evokes a 'lightness', flexibility and temporariness which contrasts with the 'heaviness', inflexibility and relative permanence of property relations variously justified by the ideologies of the first and second spirits. We note resonances here with the various forms of ethical disenchantment expressed in Milan Kundera's Unbearable Lightness of Being (Kundera 1984) and the 'deterritorialization' imperative of schizoid capitalism explored by Deleuze and Guattari (1988) and pursued further by Hardt and Negri (2000). Boltanski and Chiapello express a discernable degree of indignation with respect to the impermanency and exclusivity wrought by networked capitalism. Indeed, the seed of such indignation was already present in Marx and Engel's famous observation, 'all that is solid melts into air' (1977 [1848]: 46) suggesting a line of continuity to the development of (post)modernity that is somewhat downplayed by Boltanski and Chiapello in their effort to 'periodize' capitalism's evolution ${ }^{10}$.

Organizing by way of projects and social/commercial networks by necessity entails selfsustaining and self-regulating groups. One is only useful insofar as one's skills, interests or talents serve the network. The lightness of networked organization brings with it a renewed ethic of expendability and renders certain (non)members of society utterly invisible. For example, there are those who will be disenfranchised or socially excluded if they have limited or no access to the requisite technologies that service the networks of the projective city. So the reticular organization which facilitates development of an information economy and innovative forms of flexible accumulation for those fortunate enough to be suitably networked, casts a shadowy propensity for new forms of 
marginalization and social injustice. These are injustices, moreover, which will, by definition be invisible to the new spirit that justifies and supports the architecture of the projective city.

There are, of course, many parallels between the thesis presented by Boltanski and Chiapello in relation to the projective city and a range of social theoretical writing that seeks to explain or pass critical comment on the development of what has been variously termed late modernity, post-modernity, late capitalism or flexible capitalism. We refer, inter alia, to the thinking of Beck (1992), Giddens (1990), Hardt and Negri (2000), Harvey (1989), Lash and Urry (1994). The need to limit the scope of our discussion prevents a fuller examination of the relationship between Boltanski and Chiapello's critique and the many possible connections or points of disjuncture with such literature. In this context, however, we would like invoke the work of one contemporary social theorist, Zygmunt Bauman $(2000,2003)$, who has made an explicit link between Calvino and the themes of 'lightness' and 'liquidity' in late modern society.

Bauman (2003: $x$-xi) finds particular fecundity in Calvino's account of Leonia in thinking about a paradigm for what he terms 'liquid modernity'. According to Calvino:

The city of Leonia refashions itself every day: every morning the people wake between fresh sheets, wash with just-unwrapped cakes of soap, wear brand-new clothing, take from the latest model refrigerator still unopened tins, listening to the last-minute jingles from the most up-to-date radios (1974: 114).

In Leonia, then, we find a polity in which the consumption of the new, the fashionable and technologically innovative is driven to a neurotic excess which necessitates an equal and opposite drive to discard and dispose of the old. Indeed, Calvino asks whether the passion of Leonia's residents is truly 'the enjoyment of new and different things' and not, in actual fact, 'the joy of expelling, discarding, cleansing itself of a recurrent 
impurity' (1974: 114); an intriguing purgative twist to the theme of commodity fetishism. Here we are offered an image of the ultimate disposable society which, at the limits of its logic, exposes itself to the threat of being literally destroyed by an avalanche of the mountains of 'rubbish' that build up relentlessly on the outskirts of the city. Reflecting on the parallels between the neurotic preoccupations of advanced modernity and Leonia, Bauman asks:

Are not the residents of our liquid modern world, just like the residents of Leonia, worrying about one thing while speaking of another? They say their wish, passion, aim or dream is 'to relate'. But are ... they indeed after relationships that hold ... or do they, more than anything else, desire those relationships to be light and loose, so that... they could 'be thrown aside at any moment'? (2003: $x$ $x i$, our emphases).

In Bauman's, account of emerging capitalist social relations, as in Boltanski and Chiapello's, 'lightness' comes to represent a polity in which human ethics are compromised by the superficiality, transience and expendability of relations that are in the thrall of naked desire and whimsy. These texts invite us to be troubled by the expediency of the network society, by the relational 'nomadism' on which liquidity is predicated and thus by the loss of some imagined essence of humanity.

\section{Calvino and the virtual}

Following more imaginative traditions of management literature and organizational theory, we contend that organization of the urban world - especially when approached from the perspective of Calvino's literary genius - offers a powerful suprametafora that can assist in thinking critically about organizations in novel ways. This is particularly true, for example, with respect to the advent of ICTs and their facilitation of virtual 
organization. Although Calvino died in the mid-1980s prior to the emergence of the worldwide web, world market domination by Microsoft and Apple, proliferation of the desktop PCs, social networking and other computer-mediated forms of communication, he had some insightful and prescient things to say about such technologies. Anticipating what he refers to as the 'second industrial revolution', Calvino remarks that, 'unlike the first, [it] does not present us with such crushing images as rolling mills and molten steel, but with "bits" in a flow of information traveling [sic] along circuits in the form of electronic impulses. The iron machines still exist but they obey the orders of weightless bits' (1996 [1988]: 8). Similarly, in one of the 'Trading Cities', 'Ersilia' in Invisible Cities, Calvino invokes the image of a community that physically maps social relations using strings, 'black or gray or black-and-white according to whether they mark a relationship of blood, or trade, authority, agency. When the strings become so numerous that you can no longer pass among them, the inhabitants leave: the houses are dismantled; only the strings and other supports remain' (1974: 76).

This highly evocative imagery, we suggest, speaks to the complex forms of interrelationship mirrored in the calculative simulacra that go to make up the computer programmes and cross-referencing databases that enable the multitudinous variety of virtual interaction supplied via the Internet and other such networking media. Calvino provides us with an image par excellence of the machinery that produces the architecture of Boltanski and Chiapello's projective city. Nowhere is this better exemplified than in the proliferation and popularity of 'social networking' Internet sites (Grassman and Case, 2010). Emerging communities on the Internet have, of course, become the subject of social scientific scrutiny in recent years. A Working Group of the International Federation for Information Processing, for example, organized a conference on the theme of 'Massive Virtual Communities', adding a semantic element of 'weight' to the 'weightless flow of bits'. An extract from the call for papers reads: 
Prominently within the gaming community, but also within other communities on the internet, very huge virtual communities begin to evolve. In games, an average number of people that is comparable to a smaller city is online at the same time, thus forming a proper society. People share their pictures and videos, they meet and date in virtual communities. In Second Life, even big companies start virtual branches to enhance customer relations. It is likely that this phenomenon will become even more significant in the near future for gaming, for business and private purposes, maybe even for administrative and political functions. It is already obvious that those massive virtual communities will have a substantial impact on society, economics, art, and - last but not least technology (IFIP 2008, added emphases).

The virtual city is a reality already it would appear; or should we say, following Baudrillard (1983) and Virilio (1998), a hyper-reality of bits and network flows, of Avatars and digitally mediated simulacra? But what of the future of such 'massive virtual communities'? Calvino offers this observation:

Thus, when traveling [sic] in the territory of Ersilia, you come upon the ruins of the abandoned cities, without the walls which do not last, without the bones of the dead which the wind rolls away: spider-webs of intricate relationships seeking a form (1974: 76).

Is this not a perfectly apt metaphor for the networked society, virtual organization and their likely legacy? It is suggestive of IT systems methods whose diagrammatical mappings metonymically reduce human and non-human relationship to lifelessly neat lines, boxes and calculative functions: 'intricate relationships seeking a form'. Calvino's imagery urges us to not lose sight of the metaphysical dimension of such mapping and the anthropology which brings to these webs an emotional heart and sensate embodiment but which, nonetheless, is subject to the universal laws of transience. Yet, 
in a post-apocalyptic scenario which leaves our planet bereft of civilization, might an extraterrestrial social scientist discover Ersilia not so much in the ruins of abandoned physical cities as in the digital coding of data, programmes and networks on computer memory chips that make up virtual cities? Such, perhaps, is how the destiny of a civilization based on the polity of the projective city - the end of its history, if you will might be imagined.

\section{Conclusion}

We set out in this article to consider the possibilities of the city as metaphor and, in particular, to explore the way in which images of the city can inform differing polities and ethics of human organization. From its earliest inception, we contend, the city has taken on a metaphorical significance for human communities; being, at one and the same time, a discursive textual product of culture and, reciprocally, provider of artefacts and architecture that produces culture and meaning. From our perspective, the city can be interpreted as a trope that operates bi-directionally in cultural terms. It is a sign that can be worked to serve the principles of both metonymy and synecdoche. In pursuit of the metaphorical possibilities and limitations of the city, we found it fruitful to read and criticize possibilities for organization and organizing through the literary sensibilities of Italo Calvino and, in particular, his novel Invisible Cities. Calvino's imagination and principle of 'lightness' prompted us to adopt a critical stance toward metonymical representations of the city that privilege narrowly performative and 'weighty' agendas. Our purpose here was to provide an antidote to the reductive heaviness of economic discourse which, in Burke's terms, serve to 'bureaucratize' the imagination (Burke, 1968: 225-9).

It is not that the principle of lightness is viewed as some kind of moral good in any of the literatures we invoked. On the contrary, to return to the alchemical allusion we made 
earlier, it is the darker and heavier sentiments of saturn that triumph over the lightness of mercury in the accounts of Calvino, Bauman and Boltanski and Chiapello when it comes to the critique of reticular, flexible and connectionist social orders. This may appear, at first sight, like a contradiction in our argument. But it is better understood, we suggest, as a paradox. The lightness of the city metaphor in the hands of Calvino, Bauman and Boltanski and Chiapello is fundamentally non-reductive and thus avoids the kind of performative reification and essentialism that, we contend, is implicit in the account of economic order offered by Porter. This does not imply that 'lightness' connotes an ethical good; merely that it opens up spaces of interpretative possibility that more accurately reflect the lived experience of contemporary western social and organizational worlds. The representational possibilities of lightness paradoxically lead to critically dark, melancholic, pessimistic and 'heavy' interpretations of the moral orders enacted under the auspices of the projective city.

Our analysis of the symbolism and rhetorical appeal of Michael Porter's diamond model of economic organization was intended to open up a critical space for alternative representations of social relationships. Through the sociological lens that Boltanski and Chiapello fashion in their New Spirit of Capitalism, we were able to take the conception of 'lightness' further by looking at its implications for emerging networked societies. The principle of lightness, for Boltanski and Chiapello, carried a pejorative ethical connotation in terms of its exclusionary potential, as the polity of the projective city brought with it a series of concerns about the idea of social justice under late capitalism. These concerns were paralleled by the thoughts of Zygmunt Bauman with respect to the transience and fluidity of social relations within 'liquid modernity'. Once again, we found imaginative images from Calvino's Invisible Cities that reinforced the political and ethical messages supplied by Boltanski and Chiapello and Bauman. What emerges from our theoretical synthesis is a perspective through which to understand the contradictions and consequences of using heavy images of the city to explain and inspire organizational practices in a networked, light, flexible and liquid (Bauman 2000) capitalism. The 
analysis makes it possible to discern the ethical consequences of abusing dogmatic heaviness when employing urban images of organization.

For Perelman, the goal of any argumentation is either to generate support for the theses presented or to create, in the audience, a predisposition which will manifest itself at the appropriate moment (Perelman \& Olbrechts-Tyteca, 1958: 91). This is a goal that, contra formal logic, can only be achieved if the argumentation is sensitive to an intended audience's characteristics and view of the world. This means that, at the moment of analyzing the organizational verisimilitude or exploring imaginative possibilities of Calvino's cities, we have linked our arguments to the imagined characteristics of a Culture \& Organization readership that our discourse is addressed to. We do not know if Porter was able to do this for his readerships through his imagined cities and diamond metaphor. Sales of his books and evidence of popular influence would suggest he did. Despite such success, we can report that he does not persuade us. Far more convincing, for us, are the socially critical, subtle and scholarly fashioned images of cities offered by Boltanski and Chiapello (2005); images which cast particular lights and shadows on the complexities of capitalist social organization and which a revelatory of an ethics, politics and new spirit of the projective city.

Our purpose in this article is not to offer didactic forms of methodology or theory per se - that is, relatively fixed ways of doing organizational research or organization theory but, rather, to reflexively demonstrate a theoretical and methodological sensibility inspired by synthesizing literary and sociological approaches to reading social order. We anticipate that each reader would think of different organizations prompted by exposure to our selection of city narratives from Calvino, Porter, Bauman and Boltanski and Chiapello. And this requisite interpretative variety is exactly what we are interested in promoting and discussing. In such variation, we suggest, lies the power of the city to regenerate itself as an imaginative and provocative organizational image. 


\section{References}

Alvesson, M. 1993. The play of metaphor. In J. Hassard and M. Parker (eds)

Postmodernism and organization, 114-131. London: Sage.

Barthes, R. 1988 [1967]. The semiotic challenge. Oxford: Blackwell.

Baudrillard, J. 1983. Simulations. New York: Semiotext(e).

Bauman, Z. 2000. Liquid modernity. Cambridge: Polity Press.

Bauman, Z. 2003. Liquid love: On the frailty of human bonds. Cambridge: Polity Press.

Beck, U. 1992. Risk society: Towards a new modernity. London: Sage.

Boltanski, L. and Chiapello, E. 2005. The new spirit of capitalism, trans. Gregory Elliott. London: Verso.

Boltanski, L. and Thévenot, L. 1991. De la justification : Les économies de la grandeur. Paris: Gallimard.

Boltanski, L. and Thévenot, L. 2006. On justification: Economies of worth, trans. Catherine Porter. Princeton: Princeton University Press.

Borges, J. L. 1941 [1939]. Pierre Menard, autor del Quijote. In J.L. Borges, Ficciones. Buenos Aires: Sur.

Briand, L. and Bellemare, G. 2006. A structurationist analysis of post-bureaucracy in modernity and late modernity. Journal of Organizational Change Management 19, no, 1: 65-79.

Burke, K. 1968. Attitudes toward history. London: University of California Press.

Burke, K. 1969. A grammar of motives. London: University of California Press.

Calvino, I. 1972. Le città invisibili. Torino: Giulio Einaudi.

Calvino, I. 1974. Invisible cities, trans. Patrick Creagh. London : Vintage.

Calvino, I. 1996 [1988]. Six memos for the next millennium. London: Vintage.

Case, P. and Phillipson, G. 2004. Astrology, alchemy and retro-organization theory: An astro-genealogical critique of the Myers-Briggs Type Indicator ${ }^{\circledR}$. Organization 11, no. 4: 473-495. 
Chambers English Dictionary 1988. Cambridge: Chambers.

Code, L. 1987. Epistemic responsibility. London: University of New England Press.

Cornelissen, J. P. 2004. What are we playing at? Theatre, organization and the use of metaphor. Organization Studies 25, no. 5: 705-726.

Cornelissen, J. P., Kafouros, M., and Lock, A. R. 2005. Metaphorical images of organization: How organizational researchers develop and select organizational metaphors. Human Relations 58, no. 12: 1545-1578.

Cornelissen, J. P. 2006. Making sense of theory construction: Metaphor and disciplined imagination. Organization Studies 27, no. 1: 1579-1597.

Corvellec, H. and Hultman, J. 2012. From 'less landfilling' to 'wasting less': Societal narratives, socio-materiality, and organizations. Journal of Organizational Change Management 25, no. 2: 297-314.

Czarniawska, B. 2000. A city reframed: Managing Warsaw in the 1990s. Reading: Harwood.

Czarniawska, B. 2002. A tale of three cities: Or the glocalization of city management. Oxford: Oxford University Press.

Deleuze, G. and Guattari, F. 1988. A thousand plateaus: capitalism and schizophrenia, trans. Brian Massumi. London: Athlone Press.

Duncan, J., Robson, B. and Ley, D. 2005. City as text: The politics of landscape interpretation in the Kandyan Kingdom. Cambridge: Cambridge University Press.

Fleming, P. and Sturdy, A. 2009. 'Just be yourself!': Towards neo-normative control in organisations? Employee Relations 31, no. 6: 569-583.

Giddens, A. 1990. The consequences of modernity. Cambridge: Polity Press.

Giddens, A. 1991. Modernity and self-identity: Self and society in the late modern age. Cambridge: Polity Press.

Grassman, R. and Case, P. 2010. Virtual Intimacy: Desire and ideology in virtual social networks. In N. Panteli (ed.). Virtual Social Networks, 175-193. London: Palgrave Macmillan.

Handy, C. 1977. Understanding organizations. Harmondsworth: Penguin. 
Hardt, M. and Negri, A. 2000. Empire. Cambridge MA: Harvard University Press.

Harvey, D. 1989. The condition of postmodernity. Oxford: Blackwell.

Honneth, A. 2010. Dissolutions of the social: On the social theory of Luc Boltanski and Laurent Thévenot. Constellations 17, no. 3: 376-389.

Jullien, F. 2004. A treatise on efficacy. Honolulu: University of Hawai Press.

Jung, C. G. 1953-83. The collected works of C.G. Jung, 21 vols, Herbert Read, Michael Fordham, Gerhard Adler (eds). London: Routledge \& Kegan Paul.

Kostera, M. 2012. Organizations and archetypes. London: Edward Elgar.

Kundera, M. 1984. The unbearable lightness of being. London: Faber \& Faber.

Lakoff, G., and Johnson, M. 1980. Metaphors we live by. London: University of Chicago Press.

Lash, S. and Urry, J. 1994. Economies of signs and space. London: Sage.

Leca, B. and Naccache, P. 2008. Book review: 'Le nouvel esprit du capitalisme': Some reflections from France. Organization 15, no. 4: 614-620.

Lyotard, J.-F. 1984. The postmodern condition. Manchester: Manchester University Press.

McLaughlin, M. 1998. Italo Calvino. Edinburgh: Edinburgh University Press.

McCloskey, D. 1990. Storytelling in economics. In C. Nash and M. Warner (eds). Narrative in Culture, 5-22. New York: Routledge.

McCloskey, D. 1995. Economics and the limits of scientific knowledge. In R.F. Goodman and W.R. Fisher (eds). Rethinking knowledge: Reflections across the disciplines, 3-21. Albany: State University of New York Press.

McCloskey, D. 1998. The rhetoric of economics. $2^{\text {nd }}$ Ed. Wisconsin: University of Wisconsin Press.

Marx, K. and Engels, F. 1977 [1848]. Manifesto of the Communist Party, trans. Samuel Moore. Moscow: Progress Publishers.

Maslow, A.H. 1954. Motivation and personality. New York: Harper. 
Milanini, C. 1990. L'utopia discontinua: Saggio su Italo Calvino. Milan: Garzanti.

Morgan, G. 1986. Images of organization. London: Sage.

Morgan, G. 1989. Creative organization theory. London: Sage.

Naccache, P. and Leca, B. 2008. Luc Boltanski and Laurent Thévenot: On justification: Economies of worth. Administrative Science Quarterly 53, no. 4: 762-764.

Oswick, C. and Grant, D. 1996. The organization of metaphors and the metaphors of organization: Where are we and where do we go from here? In D. Grant and C. Oswick, (eds), Metaphor and organizations, 212-226. London: Sage.

Parker, M. 2008. Book review: The seventh city : The new spirit of capitalism by Luc Boltanski and Éve Chiapello. Organization 15, no. 4: 610-614.

Paton, S., Hodgson, D. and Cicmil, S. 2010. Who am I and what am I doing here? Becoming and being a project manager. Journal of Management Development 29, no. 2: 157-166.

Perelman, C. and Olbrechts-Tyteca, L. 1958. Traitâe de I'argumentation:Lla nouvelle rhâetorique. Paris: Presses Universitaires de France.

Porter, M. 1979. How competitive forces shape strategy. Harvard Business Review, March-April: 137-145.

Porter, M. 1980. Competitive strategy. New York: Free Press.

Porter, M. 1990a. The competitive advantage of nations. London: Macmillan.

Porter, M. 1990b. The competitive advantage of nations. Harvard Business Review, MarApril: 73-91.

Porter, M. 2007. Business and innovation. The Economist, 385(8555), November $17^{\text {th }}$ : 18-19.

Porter, T.M. 1995. Trust in numbers: The pursuit of objectivity in science and public life. Princeton, NJ: Princeton University Press.

Putnam, L. and Boys, S. 2006. Revisiting metaphors of organizational communication. In S. Clegg, C. Hardy, T. Lawrence and W. Nord, (eds), The Sage handbook of organization studies, 541-576. London: Sage. 
Putnam, L., Phillips, N. and Chapman, P. 1996. Metaphors of communication and organization. In S. Clegg, C. Hardy and W. Nord (eds) Handbook of organization studies, 375-408. London: Sage.

Varje, P., Turtiainen J. and Vaänänen, A. 2013.Psychological management: Changing qualities of the ideal manager in Finland 1949-2009. Journal of Management History 19(1): 33-54.

Virilio, P. 1998. The Virilio reader. Oxford: Blackwell.

Weber, M. 1976. The Protestant ethic and the spirit of capitalism, trans. T. Parsons, $2^{\text {nd }}$ ed. London: Allen and Unwin.

Weick, K. 1989. Theory construction as disciplined imagination. Academy of Management Review 14: 516-531.

Wittgenstein, L. 1978 [1953]. Philosophical investigations, trans. G.E.M. Anscombe. Oxford: Blackwell.

\section{Notes}

\footnotetext{
${ }^{1}$ Metonymy and synecdoche are classical terms denoting linguistic tropes commonly used in rhetorical analysis and literary criticism. Metonymy can be defined as, 'a trope in which the name of one thing is put for that of another related to it', and synecdoche is typically used to mean, 'the figure of putting part for the whole, or the whole for part' (Chambers English Dictionary 1988). In this article we stretch the classical meaning of metonymy and synecdoche casuistically so that analytical associations can be made with Calvino's literary tropes of 'heaviness' and 'lightness'. In this respect we draw inspiration from Kenneth Burke's semantic experimentation with these terms. For Burke (1969: 503), metonymy can be 'substituted' for reduction and synecdoche for representation. Thus for Burke, 'The basic "strategy" in metonymy is ... to convey some incorporeal or intangible state in terms of the corporeal or tangible' (1969: 506). Drawing on Burke's critique of realist scientific reduction of reality to material causes, we equate metonymy with the rhetorically heavy move of reducing social relations to economic causes. By contrast, 'We might say that representation (synecdoche) stresses a relationship or connectedness between two sides of an equation' (1969: 509, original emphases). In our article, therefore, we use synecdoche as a trope which resists the reduction of quality to quantity. The 'lighter' and synecdochic rhetorical strategy in this specific sense privileges acts of representation within structures of social scientific explanation.

${ }^{2}$ See also, Kostera (2012) for a discussion of organization and archetypes.

${ }^{3}$ In Jungian analytical psychology the principium individuationis is a process by which the individual Self develops out of an otherwise undifferentiated unconscious.

${ }^{4}$ While Boltanski and Chiapello's work has arguably been more influential in French sociological circles than in the English speaking world (Leca and Naccahe 2008), their work has been employed and cited sympathetically by a variety of critical management and organization studies scholars. See, inter alia, Briand and Bellemare (2006), Corvelec and Hultman (2012), Fleming and Sturdy (2009), Paton et al. (2010), and Varje et al. (2013).
} 
${ }^{5}$ It is somewhat ironic that we invoke Boltanski and Chiapello to explore the principle of 'lightness' given that, as Parker (2008: 610) observes in his critical review of The New Spirit of Capitalism, it is 'A book that, with its sheer weight of words about the world, proclaims its importance'.

${ }^{6}$ See Parker (2008) for a critical review of The New Spirit of Capitalism and Leca and Naccache (2008) for an assessment of both the affirmative and critical reception of Le Nouvel Esprit du Capitalisme in France following its publication there in 1999.

${ }^{7}$ As Boltanski and Chiapello claim: 'We shall see how management discourse, which aims to be formal and historical, general and local, which mixes general precepts with paradigmatic examples, today constitutes the form par excellence in which the spirit of capitalism is incorporated and received' (2005, p.14, original emphases).

${ }^{8}$ Parker (2008: 611) is not particularly receptive to their computer-generated analysis, making the rather acerbic observation that 'this part of the book reads a bit like an odd MPhil thesis'.

${ }^{9}$ See Cicmil \& Hodgson (2006), pp.5-6, for a useful review of this body of criticism.

${ }^{10}$ Leca and Naccache (2008) document and trace French Marxist critiques of Le Nouvel Esprit $d u$ Capitalisme. 